\title{
REALTIME DATABASE SENSOR MENGGUNAKAN ARDUINO UNO UNTUK KEPERLUAN SISTEM INFORMASI
}

\author{
Muhammad Akbar \\ akbar.stmikhdy@gmail.com \\ Pascasarjana Sistem Komputer STMIK Handayani Makassar
}

\begin{abstract}
Abstrak
Penelitian ini fokus kepada bagaimana membangun sebuah sistem sensor yang selanjutnya akan secara otomatis tersimpan pada database menggunakan mikrokontroller arduino uno dan ethernet shield, penyimpanan selanjutnya akan bersifat realtime. Tujuan dari penelitian ini yakni adalah tersedianya sebuah sistem sensor yang dapat secara realtime menyimpan data pada database. Setelah tersimpan ke dalam database, maka akan memudahkan programmer dalam merancang sistem informasi yang bersifat multiplatform. Hasil dari penelitian adalah tersimpannya data masukan dari sensor-sensor (LDR) ke dalam database dengan menggunakan mikrokontroller arduino uno secara realtime. Kesimpulan yang dapat ditarik dari penelitian ini adalah setiap sensor(LDR) yang digunakan mampu menyimpan data-data berupa data digital pada database secara realtime. Adapun saran untuk penelitian selanjutnya yakni memperhatikan posisi sensor apabila menggunakan sensor cahaya, agar kiranya ditempatkan pada posisi terbaik untuk menerima sumber cahaya.
\end{abstract}

Kata kunci : sensor LDR, Database, Realtime, Arduino Uno.

\section{Pendahuluan}

Era digitalisasi pada zaman sekarang tidak terlepas dari peranan-peranan berbagai macam teknologi dari berbagai platform dan vendor. Sistem informasi merupakan makanan sehari-hari yang seolah-olah menjadi kewajiban bagi penikmat dunia digital, baik itu skala lokal maupun skala global (internet). Sistem informasi ini tentu saja dapat berjalan dengan baik apabila ditopang dengan sistem penyimpanan informasi berbasis database, apalagi jika database yang digunakan menggunakan sistem waktu nyata (realtime). Sistem informasi seperti informasi kamar hotel, informasi parkiran, informasi-informasi untuk keperluan smart city,smart building, smart home dan, sistem informasi lainnya membutuhkan infrastruktur perangkat keras berupa sensor yang terhubung ke database secara realtime. Namun kenyataan dilapangan masih terdapat berbagai macam masalah dalam sistem informasi database tersebut.

Masalah yang sering dihadapi pada sistem informasi konvensional yang ada khususnya di Indonesia ini, kebanyakan masih menggunakan tidak terhubung ke jaringan lokal maupun global dan tidak bersifat realtime[1]. Ini dikarenakan pengumpulan data-data yang dilakukan masih menggunakan sistem manual. Hal ini tentu saja menyulitkan pengguna akhir untuk dapat mengakses sistem informasi seperti di atas. Untuk itu dengan adanya sistem infratruktur perangkat keras sensor yang terhubung ke database yang dapat digunakan sebagai sistem informasi secara realtime ini diharapkan mampu menjadi salah satu solusi untuk mengatasi masalah tersebut.

\section{Metode}

Keseluruhan sistem pada penelitian ini dapat dilihat pada gambar di bawah ini:

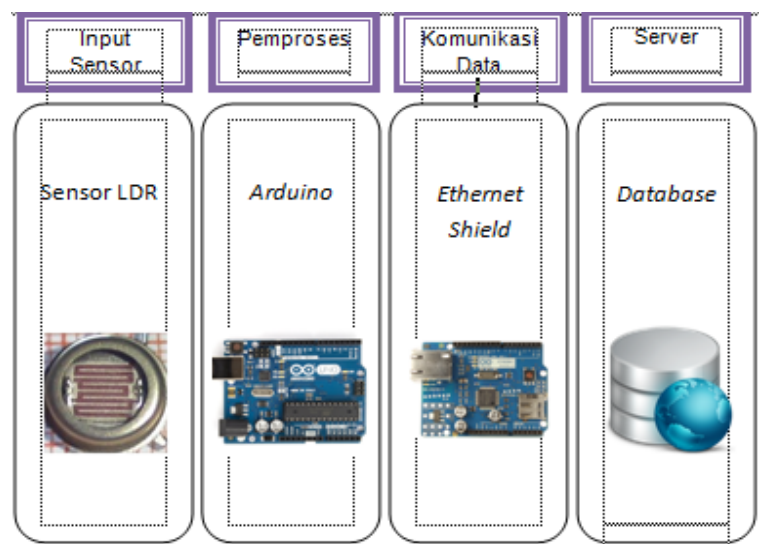

Gambar 1. Skema sistem [1] 


\subsection{Sensor Cahaya (LDR)}

Pada gambar 1 di atas menjelaskan mengenai skema sistem secara keseluruhan dari input sampai dengan output. Pada penelitian yang dilakukan menggunakan sensor cahaya atau sensor Ligth Dependent Resistor (LDR). Sensor ini adalah sensor jenis resistor yang nilai hambatannya dipengaruhi oleh cahaya yang diterima olehnya. Besarnya nilai hambatan pada LDR tergantung pada besar kecilnya cahaya yang diterima oleh LDR itu sendiri [2]. Dengan menempatkan sensor ini pada setiap ruas slot parkir, apabila sensor ditutupi oleh mobil, maka tegangan awal pada arduino senilai 1023 akan berubah sesuai dengan, sehingga dapat dihasilkan nilai digital 1 atau 0[2].

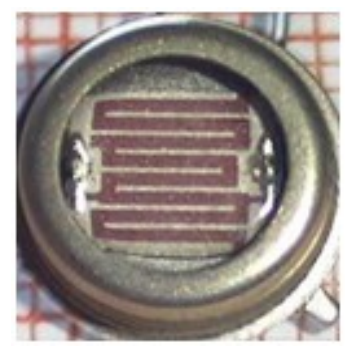

Gambar 2. Sensor LDR [2]

\subsection{Arduino Uno Rev. 3}

Untuk pemproses menggunakan mikrokontroller Arduino Uno Rev. 3. Arduino UNO merupakan rangkaian mikrokontroller yang telah terintegrasi dengan fungsi tambahan lainnya, seperti tombol reset, pengendali range suatu value dari suatu sensor dan fungsi-fungsi penting lainnya. Mikrokontroller ini mempunya pin input-output analog sebanyak 6 pin dan pin digital sebanyak 14 dengan beberapa pin diantaranya berfungsi sebagai $t x r x$ dan fungsi lainnya[3]. Perangkat ini akan mengkonversi sisa tegangan hasil hambatan dari sensor LDR. Nilai voltase arduino uno awal sebesar 5 volt, tapi pada prinsip dasarnya nilai tegangan kerja pada suatu rangkaian akan bernilai lebih kecil setelah melewati beberapa komponen pada rangkaian tersebut., setelah masukan hambatan dari sensor LDR nilai teganga tersebut akan berubah sesuai dengan hambatan dari sensor (data pada tabel hasil penelitian). Data dari sensor, akan diproses dan dikirim oleh arduino yang selanjutnya akan dikirim ke database melalui perantara ethernet shield.

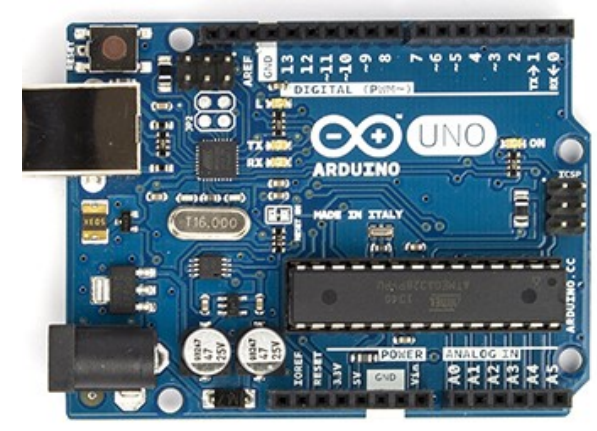

Gambar 3. Arduino Uno Rev. 3 [3]

\subsection{Ethernet Shield}

perangkat ini berfungsi untuk melakukan komunikasi data/mengirimkan data via jaringan dengan teknologi ethernet menggunakan kabel UTP dengan konektor RJ-45. Perangkat inilah yang akan mengantarkan data dari sensor ke database melalui jaringan via port 80 pada protokol http [4]. Pada listing code IDE arduino, ethernet shield diset berfungsi sebagai client yang akan mengirimkan data ke server database. Jadi pemberian alamat IP menjadi hal penting dalam penelitian ini. Alamat IP client (ethernet shield) dan alamat server database beserta port yang digunakan harus benar-benar diset sesuai dengan skema jaringan yang ada. Kesalahan dalam pemberian alamat IP akan mengakibatkan data dari sensor tidak akan tersimpan ke database. 


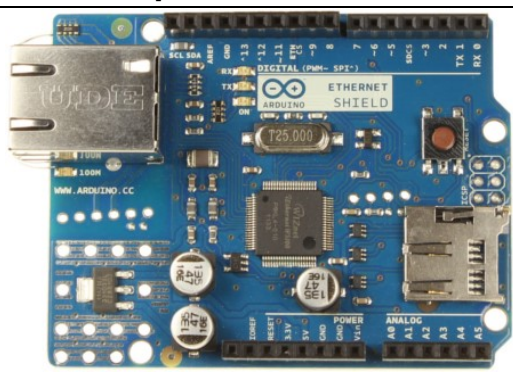

Gambar 4. Arduino Ethernet Shield [4]

\subsection{Database}

Output terakhir dari penelitian ini adalah database itu sendiri. System database yang digunakan disini adalah database mysql dengan nama "coba" dan nama tabel "tblcoba". Gambar 5 memperlihatkan bagaimana struktur penggunaan database.

\begin{tabular}{|c|c|c|c|c|c|c|c|}
\hline & $\#$ & Column & Type & Collation Attributes & Null & Default & Extra \\
\hline$\square$ & 1 & $\underline{\text { no }}$ & int(11) & & No & None & AUTO_INCREMENT \\
\hline$\square$ & 2 & sensor1 & $\operatorname{int}(11)$ & & No & None & \\
\hline$\square$ & 3 & sensor2 & $\operatorname{int}(11)$ & & No & None & \\
\hline$\square$ & 4 & sensor3 & $\operatorname{int}(11)$ & & No & None & \\
\hline$\square$ & 5 & sensor4 & $\operatorname{int}(11)$ & & No & None & \\
\hline$\square$ & 6 & sensor5 & $\operatorname{int}(11)$ & & No & None & \\
\hline
\end{tabular}

Gambar. 5. Struktur System Database [1]

Terlihat dengan jelas pada gambar 5 di atas, database pada sistem ini menggunakan 6 kolom, yakni kolom no. Sebagai ID yang merupakan primary key dan bersifat auto increment, kemudian kolom sensor 1 sampai dengan sensor 5 dengan tipe data integer. Data dari sensor melalui arduino akan langsung disimpan ke dalam database ini, dan akan disesuaikan dengan masing-masing kolom sensornya.

\section{Hasil dan Pembahasan}

Setelah proses uji coba pada penelitian ini, maka hasil yang didapatkan sebagai berikut :

Tabel 1. Percobaan sensor

\begin{tabular}{|c|c|c|c|c|c|c|c|}
\hline \multirow{2}{*}{ NO } & Jam & \multicolumn{5}{|c|}{ Hasil } & \multirow{2}{*}{ Cahaya } \\
\cline { 2 - 7 } & Percobaan & S1 & S2 & S3 & S4 & S5 & \\
\hline 1 & 09.10 & $100 \%$ & $100 \%$ & $100 \%$ & $100 \%$ & $100 \%$ & Matahari \\
\hline 2 & 11.35 & $100 \%$ & $100 \%$ & $100 \%$ & $100 \%$ & $100 \%$ & Matahari \\
\hline 3 & 12.01 & $100 \%$ & $100 \%$ & $100 \%$ & $100 \%$ & $100 \%$ & Matahari \\
\hline 4 & 13.23 & $100 \%$ & $100 \%$ & $100 \%$ & $100 \%$ & $100 \%$ & Matahari \\
\hline 5 & 17.05 & $100 \%$ & $100 \%$ & $100 \%$ & $100 \%$ & $100 \%$ & Matahari \\
\hline 6 & 19.09 & $100 \%$ & $100 \%$ & $100 \%$ & $100 \%$ & $100 \%$ & Lampu \\
\hline
\end{tabular}

Pada table 1 yakni percobaan, kondisi percobaan sensor dilakukan pada 5 waktu berbeda, dimana dari pukul 09.10 sampai 17.05 sumber cahaya yang digunakan adalah matahari, dan hasilnya sensor bekerja baik. Kemudian untuk kondisi malam hari, yakni pukul 19.09 dengan sumber cahaya lampu, sensor bekerja secara baik pula.

$100 \%$ adalah nilai akurasi pembacaan sensor ketika membaca kondisi ada dan tidak adanya kendaraan mobil. $100 \%$ di dapatkan dari rumus :

$$
\text { Akurasi data }(\%)=\frac{x}{y} \times 100 \%(1)
$$




\section{ILKOM Jurnal Ilmiah Volume 9 Nomor 1 April 2017}

Ket : $\mathrm{x}=$ Keberhasilaan pembacaan sensor (dikatakan berhasil ketika sensor menghasilkan nilai 0 ketika tidak ada kendaraan mobil dan 1 ketika ada kendaraan mobil).

$\mathrm{y}=$ Jumlah percobaan pengiriman data pada komunikasi serial monitor arduino

Jadi $100 \%$ di dapatkan dari,

Akurasi data $(\%)=\frac{10}{10} \times 100 \%=100 \%(2)$

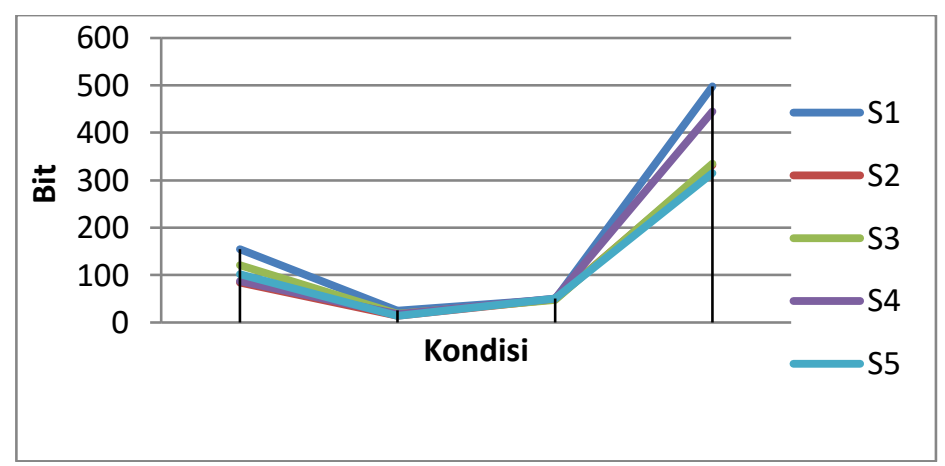

Gambar 6. Grafik nilai rata-rata tegangan sisa arduino

Gambar 4. Di atas menunjukkan grafik statistik pengaruh hambatan pada LDR terhadap tegangan pada arduino. Tegangan pada arduino berjumlah 1023 atau senilai 4,20 volt pada pin I/O. Setelah dihambat oleh LDR, didapatkan hasil seperti pada grafik di atas.

Tabel 2. Rata-rata sisa tegangan arduino setelah hambatan sensor

\begin{tabular}{|c|c|c|c|c|c|c|c|}
\hline \multirow{2}{*}{ No } & \multirow{2}{*}{ Kondisi } & \multicolumn{5}{|c|}{ Rata-rata sisa nilai bit tegangan } & Sumber \\
\cline { 3 - 8 } & & Sensor1 & Sensor2 & Sensor3 & Sensor4 & Sensor5 & Cahaya \\
\hline 1 & Pagi & 154,4 & 84,5 & 120,9 & 87,4 & 101,7 & Matahari \\
\hline 2 & Siang & 24,9 & 14,2 & 18,4 & 17,6 & 14 & Matahari \\
\hline 3 & Sore & 49,1 & 49,2 & 48,3 & 50,6 & 50,7 & Matahari \\
\hline 4 & Malam & 498 & 332 & 335 & 445 & 315 & Lampu \\
\hline
\end{tabular}

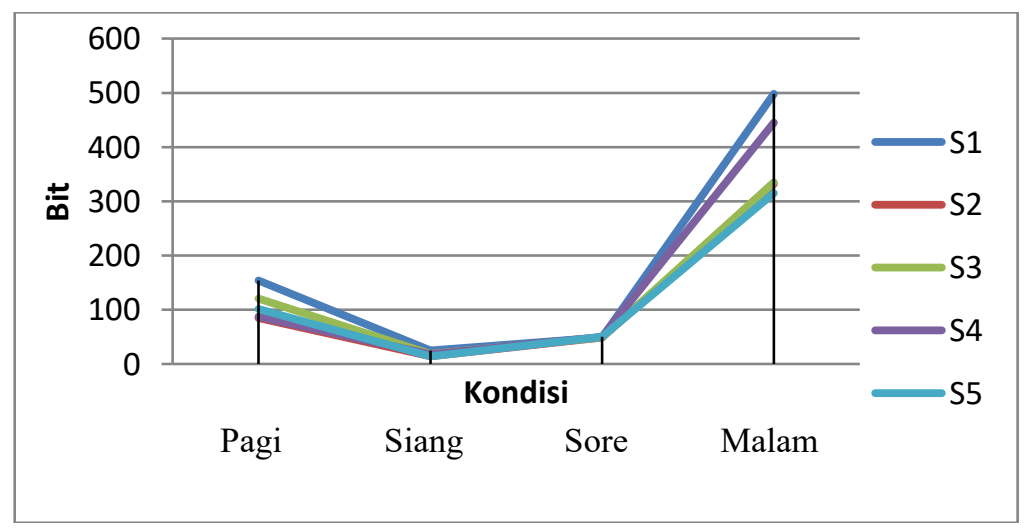

Gambar 7. Nilai rata-rata bit sisa tegangan arduino setelah hambatan sensor

$\begin{array}{cccccc}\text { no } & \text { sensor1 } & \text { sensor2 } & \text { sensor3 } & \text { sensor4 } & \text { sensor5 } \\ 1 & 0 & 0 & 0 & 0 & 0 \\ 2 & 0 & 0 & 1 & 1 & 0 \\ 3 & 1 & 1 & 1 & 0 & 0 \\ 4 & 1 & 1 & 1 & 1 & 0\end{array}$

Gambar 8. Tampilan nilai database setelah terisi data dari sensor 


\section{ILKOM Jurnal Ilmiah Volume 9 Nomor 1 April 2017}

\section{Kesimpulan dan Saran}

Sensor bekerja baik dibeberapa kondisi seperti pagi, siang, sore dan malam hari dengan sumber cahaya matahari dan lampu. Meskipun pada percobaan awal sensor kurang mampu mendeteksi keberadaan mobil pada siang hari, tapi setelah perbaikan sensor telah mampu mendeteksi mobil dengan baik.

Titik tertinggi dari bit tegangan default arduino adalah 1023 bit, dimana ini sama dengan 4,20 volt. Sedangkan titik terendah adalah 0 bit, yang sebanding dengan 0,5 volt. Nilai 1023 dapat dicapai dengan tidak memberikan nilai cahaya sedikitput ke permukaan LDR. Meskipun tegangan kerja arduino adalah 5 volt, namun tegangan tersebut tidak akan sama dengan tegangan pada pin input output, karena beberapa komponen dari rangkaian arduino akan menghambat atau mengurangi nilai tegangan yang ada.

Pada arduino pin digital hanya dikenal nilai biner 1 dan 0 . Nilai 0 dihasilkan ketika tegangan sisa setelah hambatan pada LDR sebesar kurang lebih di bawah 550 bit atau di bawah 2,1 volt. Sedangkan nilai 1 dihasilkan ketika tegangan sisa pada arduino kurang lebih di atas 560 atau senilai 2,2 volt.

Setelah melewati berbagai proses didalam penelitian disertai dengan banyak percobaan, maka dapat disampaikan beberapa saran untuk perkembangan dari penelitian ini yakni adalah penggunaan perangkat keras komunikasi data akan lebih efektif dan efisien jika menggunakan Arduino Wifi Shield, sehingga dalam proses perancangan sistem dapat dipermudah dengan teknologi nirkabel. Atau perangkat lain di luar arduino yang pemproses dan komunikasi datanya telah onboard dalam satu perangkat seperti rasberry.

Untuk penggunaan sensor, dapat menggunakan sensor cahaya lain yang lebih sensitif seperti photodioda, namun jika menggunakan sensor ini haruslah dibatasi range nilai untuk logika 1 dan 0 , karena sensor yang terlalu sensitif juga dapat mengurangi efisiensi dari sistem secara keseluruhan. Dapat juga menggunakan sensor lain seperti sensor proximity.

\section{Daftar Pustaka}

[1] Zahir Zainuddin, Adnan, Muhammad Akbar. 2015, Tesis "Model Infrastruktur Perangkat Lunak Sensor Untuk Informasi Ketersediaan Parkir", Pascasarjana STMIK Handayani, Makassar.

[2] Teknik Elektro. Link web http://teknikelektronika.com/pengertian-Idr-light-dependent-resistor-caramengukur-Idr/ diakses pada 05 Maret 2017

[3] Arduino corp. “ Arduino Genuino / UNO". Link web. https://www.arduino.cc/en/Main/ArduinoBoardUno diakses pada 05 Maret 2017

[4] Arduino corp. "Arduino Ethernet Shield". Link web https://www.arduino.cc/en/Main/ArduinoEthernetShield diakses pada 05 Maret 